\title{
Balkanologie
}

Balkanologie Revue d'études pluridisciplinaires

Vol. VII, $n^{\circ} 2$ | 2003

Volume VII Numéro 2

\section{Sami Frashërior Šemseddin Sami?}

Mythologization of an Ottoman Intellectual in the Modern Turkish and Socialist Albanian Historiographies based on «Selective Perception»

\section{Bülent Bilmez}

\section{(2) OpenEdition}

12 Journals

Electronic version

URL: http://journals.openedition.org/balkanologie/492

DOI: 10.4000/balkanologie.492

ISSN: 1965-0582

\section{Publisher}

Association française d'études sur les Balkans (Afebalk)

\section{Printed version}

Date of publication: 1 December 2003

Number of pages: $19-46$

ISSN: $1279-7952$

\section{Electronic reference}

Bülent Bilmez, « Sami Frashërior Šemseddin Sami? », Balkanologie [Online], Vol. VII, n 2 | 2003, Online since 19 February 2009, connection on 17 December 2020. URL : http://journals.openedition.org/ balkanologie/492 ; DOI : https://doi.org/10.4000/balkanologie.492 


\title{
SAMI FRASHËRI OR ŠEMSEDDIN SAMI? MYTHOLOGIZATION OF AN OTTOMAN INTELLECTUAL IN THE MODERN TURKISH AND SOCIALIST ALBANIAN HISTORIOGRAPHIES BASED ON « SELECTIVE PERCEPTION 》
}

\author{
Bülent Bilmez*
}

It may be best to start by clarifying the limits of the subject of this paper, which is an early outcome of a long-term research project. It is not the purpose of this paper to write a biography of Shemseddin Sami Frashëri (1850-1904) or to present a thorough study of his works ${ }^{1}$. It is very well known that, as a novelist, journalist, lexicographer and self-taught linguist Sami was one of the most productive intellectuals of the Ottoman Empire in the second half of the nineteenth century and has been praised both in the Turkish and Albanian historiographies in the twentieth century for his contributions to Turkish or Albanian nation-building respectively.

\section{Empirical framework}

As the title suggests, this paper will explore the different perceptions of his activities and works in the Albanian and Turkish historiographies. A symbolic expression of this radical difference can be seen in the usage of two different names in Turkey and Albania today. Two different versions of his name have prevailed in the collective memories of both countries Šemsettin Sami in Turkey and Sami Frashëri in Albania ${ }^{2}$. Each of these two names is praised by the historiography of each of these two countries as one of the leaders of nationalism in each country, i.e. of "Turkism" and "Albanianism", respectively. The ex-

\footnotetext{
• Department of History, Yeditepe University, Istanbul, Turkey (bbilmez@hotmail.com)
}

\footnotetext{
${ }^{1}$ I would like to express my thanks to N. Clayer (Paris), M. Tunçay (Istanbul) and S. Schwander (London) for their comments on an early version of this text and to J. Dranqolli (Prishtina) and ö. Celiktemel for their valuable help that made this article finish.

'In this paper I will either call him 'Shemseddin Sami Frashèri' or, shortly, 'Sami', as this is the component of his name used by both sides.
} 
ploration of these radical differences and a discussion of them would, I believe, be very instructive because they present a very good example of the use of history and historical figures in the process of nation building in general.

Two different readings of his activities and works in the modern Turkish (from 1923 to the present) and socialist Albanian (1945-1990) historiographies - both of which mythologize him - will be explored through an examination of popular and academic historiographies in both countries ${ }^{3}$. It must be underlined that "Albanian historiography" in this paper does not include the works of the Albanian speaking historiographers from Kosovo and Macedonia, but only of those from Albania of a certain period4. Turkish historiography is also restricted here to the republican era. Although I believe that the image of Sami in the historiography of the Turkish Republic and especially of socialist Albania cannot be understood without taking its roots in the previous periods into consideration, such (temporal and geographical) restriction seems to be very practical and reasonable, because each of these periods is rather a "compact" time period, as in each case (especially in socialist Albania) there was an ideological approach of the state towards history.

In spite of this necessary time restriction in both cases, some observations about the construction of this image in the previous periods will be briefly mentioned. The approaches in each of these periods will not be taken as static. Different approaches and perceptions in any of these periods will be analysed and the changes within each period will be paid special attention.

\footnotetext{
${ }^{3}$ In trying to assess which side is rather right and in what respect, one should also take into consideration the possibility that Sami did contribute to this confusion through the complex attitudes expressed in his works and activities.
}

${ }^{4}$ Regarding the perception of Sami in the Albanian and Turkish historiographies in general, one can easily distinguish the peculiar attitude of two authors from the others. One of them is a prominent scholar from Kosovo, Hasan Kaleshi, and the other one is the Albanian writer from Turkey, Necip Alpan. Both of them differ from the others by acknowledging both the Turkish and Albanian nationalisms of Sami, without regarding it as a problematical issue. The works of these two authors, whose attitudes share similarities with those of Sami himself, are not included in this paper. (See : Alpan (Necip), "Dünyaca Paylașılamayan Bir Sima : Șemsettin Sami ", Yeni Tanin, 4 (1522), 3 Nisan 1969 ; Alpan (Necip), Tarih Ișiğinda Bugünkü Arnavutluk, Ankara : Kardeș, 1975 ; Alpan (Necip), Prizren Birliği ve Arnavutlar, Ankara : Çağdaș Basımevi, 1978 ; Alpan (Necip), Albanolojinin Iș̆ğında : Arnavut Alfabesi Nasıl Doğdu (100-Vjetori i Abecesë Shqipe), Ankara, 1979 ;Alpan (Necip), Tarihin Ișı̆ında Arnavutluk'un Bağımsızlğı ve Avlonyalı İsmail Kemal, Ankara, 1982 ; Kaleshi (Hasan), " Sami Frashëri në Letërsinnë dhe Filologjinë Turke ", Gjurmime Alabanologjike, (1), 1968 ; Kaleshi (Hasan), "Veprat Turqisht dhe Persisht të Naim Frashërit ", Gjurmime Albanologjike, (1-2), 1970 ; Kaleshi, (Hasan), " Burimet Lidhur Me Studimin e Sami Frashërit ", Buletin i Punimeve Shkencore të Fakultetit Filizofik të Prishtinës, 8 (A), 1971 ; Kaleși (Hasan), " Șemsettin Sami'nin Siyasi Görüșleri ve "Megalo-idea" Hakkındaki Düșünceleri ", Belgelerle Türk Tarihi Dergisi. Dün, Bugün, (40), Ocak 1971.) 


\section{Theoretical framework: Myth and Mythologization}

Any contemporary historian would treat the term "myth" very carefully as it is commonly acknowledged that " what seems true to one historian will seem false to another, so one historian's truth becomes another's myth, even at the moment of utterance "5. Regarding the image of Sami as a "myth", on the other hand, the following could be stated : " although any aspect of the past has the potential to live on as myth in the present, certain events and persons, because they resonate with theme of broader scope and importance, have this potential to a pronounced degree $n^{6}$.

Sami is one of such persons. The two contradicting images of Sami in these two historiographies deserve to be called as myth, even we only consider the fact that both of these images are constructed and presented by (conscious or unconscious) negligence, ignorance and distortion of the facts presented by the other side. I do not mention the facts presented in the studies by international scholars in this text, as the purpose of this paper is not " dismantling of the mythologized past $" 7$ through proving its wrongness and presenting the only truth by using "objective proofs" presented by these scholars or primary sources found in the archives. Instead of an effort of "demythologisation", a descriptive approach is chosen here that aims at giving a detailed picture of the two images of an important intellectual and the process of constructing this image. Though some may believe such "primary" and "objective" materials may help us to discuss Sami's "true identity" and to expose the process of distortion of the facts, belief in existence of (one) truth and objective fact, I think, can be seen as a naive attitude in this post modern era !

Though " "myth" in everyday parlance, often implies something "fabricated" or "not true" " 8 , the production and usage of nationalist myths are not always based on distortion or ignorance of "facts", but usually on selective perception due to the nationalist approach. In this case, history is read with partiality : those parts that do not conform to the "readers" preformulated answers or do not suit intentions / expectations of the "reader" are (either consciously or unconsciously) neglected, underestimated or even sometimes ignored. On the other hand, every detail that supports the position of the reader is carefully selected, overemphasized and used in the re/production of the myth.

Apart from these rather "innocent" ways of contributing to the mythologization process or the usage of myths, the facts may also be misrepresented

\footnotetext{
${ }^{5}$ Mcneill (William Hardy), Mythistory and Other Essays, Chicago / London : The University of Chicago Press, p. 3. (Emphasis added by Bilmez.)
}

${ }^{6}$ Cohen (Paul A.), History in Three Keys The Boxers as Event, Experience and Myth, New York : Colombia University Press, 1997, p. 212.

7 Ibid., p. 211.

${ }^{8}$ Ibid. 
intentionally. Deliberate silence about the facts that contradict a current myth is one way of this misrepresentation, but in some cases the facts may even be distorted. New information and interpretations that contradict the current myth would not lead to any doubt, unless the people are ready to question their own truth, which is usually hindered by ideological blindness - nationalism?.

\section{ŞEMSEDDIN SAMI : SAMI IN THE TURKISH HISTORIOGRAPHY}

To start with the mythologization of Sami in the Turkish historiography, the current "myth" in the Turkish historiography can be formulated as follows : Sami was a Turkish intellectual, who, as one of the pioneers of Turkish nationalism, devoted his life to Turkism and/or Turkishness. It is not very clear what is meant by "Turkishness" in the books and articles, but this so-called devotion of his has always been expressed with a total neglect of his engagement in Albanian nationalism. In Radikal, a rather non-nationalist newspaper in Turkey, on March 31, 2002, there was an article on Sami, which demonstrates the present level of this mythologization in Turkey. Unlike many other Turkish commentators, the author states that Sami " originally was Albanian ", and that his " mother tongue was Albanian". However, he is not exempt from the general mythologization, and praises Sami for his contribution to the studies of Turkish language and alphabet reform, without mentioning his Albanian nationalism ${ }^{10}$.

In order to expose the mythical image of Sami in current Turkish popular culture and the average historiography, we could also take a look at the school textbooks and popular encyclopaedias and lexicons where we can find this mythologization put concisely and directly. So far, I have been able to study the later group.

In the popular Turkish encyclopaedias and lexicons of "Who's Who?" in the history of Turkish literature and/or drama, Sami is usually represented as a Turkish linguist and author of the first novel in Turkish ${ }^{11}$, and as one of the pioneers of Turkish nationalism. From the encyclopaedias and lexicons that have been checked for entries on Sami, the majority of them starts with stating

\footnotetext{
${ }^{9}$ Though this problematic is out of the scope of this paper, it must be stated that mythologization in nationalistic discourse is naturally not only a pure intellectual activity, but may have important concrete political reasons and consequences, beside the abstract ideological ones.
}

10 Ozgürel (Avni), "Dil Ustası Șemsettin Sami ", Radikal, 31/03/oz.

${ }^{11}$ Semseddin (Sami), Taaşşuk-1 Talat ve Fitnat, İstanbul : Enderun Kitabevi, 1990 [1872]. 
that he was Turkish ${ }^{12}$. In some other encyclopaedias his nationality is not mentioned ${ }^{13}$. In one of them he is defined as an "Ottoman writer." Strangely enough, it is stated in the text of this entry that claimed by Sami that the word "Ottoman" could be used only for the state, but not for the language or nationality ${ }^{14}$. In two other encyclopaedias, the entries of which are almost identical, Sami's nationality is not stated ; however, it is noted that his mother tongue was $\mathrm{Greek}^{15}$. In an encyclopaedia published by a nationalist publishing house the nationalistic opinion about this issue is formulated very clearly : " though originally Albanian, he chose Turkish nationality; believed that Turks are a great nationality, performed surveys especially on Turkish language with a nationalistic mentality, produced valuable works that enlightened the past of Turkish language and enriched the future of it $»^{16}$.

Most of these encyclopaedias give conflicting information even on factual issues like his works and the years he lived in different places and almost all of these entries consist of laudatory writing. They praise Sami for being the writer of the first Turkish novel, the writer of the first Turkish encyclopaedia ${ }^{17}$ and the Turkish dictionary ${ }^{18}$ that was to remain the main source for all studies on Turkish language for a long time. However, with only one exception, they all neglect his activities and works that made him known as one of the pioneers of Albanian nationalism in the historiography of Albania. This one exception can be found in an encyclopaedia which, like many others, is a translation from French with some modifications and additions, but is faithful to the content of original. It contains information both on Sami's struggle on the side

12 The entry "Șemseddin Sami" in Dictionnaire Larousse, Ansiklopedik Sözlük, 1993-1994, İstanbul : Milliyet, 6, p. 2235 ; Türk Ansiklopedisi, Ankara : Milli Eğitim Basımevi, 30,1981, p. 251 ;Meydan Larousse. Büyük Lügat ve Ansiklopedi, Istanbul :Sabah, 18, (no date), p. 504 ;Büyük Larousse, Sözlük ve Ansiklopedi, İstanbul : Gelișim, 18,1986, p. 11047 ; Gelișim Hachette, Alfabetik Genel Kültür Andiklopedisi, İstanbul : Gelișim ve Yayın A.Ș., 10, (no date), pp. 4086-4087 ; Meydan-Larousse, İstanbul : Meydan Yayınevi, 11, 1989, p. 758 ; Hayat Küçük Ansiklopedi, Istanbul : Hayat, 1968, p. 1079 ; and Yeni Hayat Ansiklopedisi, İstanbul : Doğan Kardeș, 6, 1978, p. 2985.

13 Parlatır (İsmail), "Șemseddin Sami (1 Haziran 1850-18 Haziran 1904) ", Bașlangıcmdan Günümüze Büyük Türk Klasikleri, Tarih-Antoloji-Ansiklopedi, 9, 1989, pp. 111-112 ; Özön (M. Nihat), Dürder (Baha), Türk Edebiyatı Ansiklopedisi, İstanbul : Remzi Kitabevi, 1967, p. 388 ; Ana Britannica, Istanbul : Ana Yaynncllık, 29, 1994, p. 89 ;Ișik (thsan), " Șemsettin Sami n, Türkiye Yazar Ansiklopedisi, (Genișletilmiș 2. Baskı), Ankara : Elvan, 2002, p. 871 ; Özkınmlı (Atilla), " Șemsettin Sami ", Türk Edebiyatı Ansiklopedisi, 4, 1987, pp. 1071-1073 ; Gelișim Alfabetik Gençlik Ansiklopedisi, 9, 1980, p. 2313 ; Kurdakul (Șükran), " Șemsettin Sami ", Șairler ve Yazarlar Sözlüğü, İstanbul : İnkılap, 1999, pp. 613-614.

14 Türk ve Dünya Ûnlüleri Ansiklopedisi, İstanbul : Anadolu Yayıncllı, 10, 1983, p. 5206.

15 Gövsa (Ibrahim Alaettin), "Șemseddin Sami ", Meșhur Adamlar, 4, 1933-1938, pp. 367-368 ; and Resimli Yeni Lügat ve Ansiklopedi (Ansiklopedik Sözlük), İstanbul : İskit, 5, 1947-1954, pp. 2652-2653.

16 "Șemseddin Sami ", Türkiye Gazetesi Yeni Rehber Ansiklopedisi, İstanbul : İhlas Holding, 18, 1994, p. 259.

${ }^{17}$ Șemsettin (Sami), Kamusu'l A'lam, I-VI, Ankara : Kașgar Neșriyat, 1996 [1889-1898].

${ }^{18}$ Șemseddin (Sami), Kamus-i Türki, İstanbul : Alfa, 1998 [1900]. 
of the Albanian resistance against the plans of new frontiers in the Balkans after the Turko-Russian War in 1878 and also on his engagement for the creation of a (new) Albanian alphabet ${ }^{19}$.

\section{The construction of the myth based on selective perception}

Indeed Sami was already at the center of Ottoman intellectual life in the last decade of the nineteenth century, especially after he had published his French-Turkish dictionary in 1882 and his Turkish-French dictionary in 1885 . The start of publishing his major 6 volumes encyclopaedia, Kamus-ul Alam in 1888 , which was completed in 1898 , contributed very much to his reputation. Especially his dictionaries were very widely used and very much appreciated by the intellectuals of his time for whom French was the primary language that opened a window to the Western world ${ }^{20}$. His works were welcomed by the press, where we can find evaluations of his works ${ }^{21}$. Although he was forced to spend his last five years in extreme isolation, he attracted more attention as the author of a modern Turkish dictionary, which had many new peculiarities. This interest could be observed in the oppositional press of the "Young Turks" as well ${ }^{22}$. There was even a booklet on Sami published in Ottoman Turkish by İsmail Hakk1, in 1895, which was the fourth (Dördüncü Defter) in a series of studies on the biographies of the "Ottoman writers". In the booklet, Sami was eulogized for his dictionaries and other works ${ }^{23}$.

The tendency to neglect his Albanian nationalism, as well as his activities and works devoted to that cause could already be seen in the posthumous wri-

\footnotetext{
19 Büyük Larousse (op. cit.), p. 11047.
}

${ }^{20}$ For some anecdotes about the importance of his dictionaries in the intellectual life of that period, see the section below on the place of Sami in the published memoirs of the Turkish intellectuals.

${ }^{21}$ " Kamus-i Türki Hakkında Mütalaat ",Mecmua-i Edebiye, (5), 29 Recep 1318 (1900) ; " Kamus-i Türki Hakkında Mütalaat ", Mecmua-i Edebiye, (6), 6 Șaban 1318 (1900) ; "Kamus-i Türki Hakkında Mütalaat ", Mecmua-i Edebiye, (7), 16 Șaban 1318 (1900) ; " Kamus-i Türki Hakkında Mütalaat ", Mecmua-i Edebiye, (8), 20 Șaban 1318 (1900) ; Ahmet Mithat, " Kamus-ul Alam ", Tarik, 22 Mart 1315 [1899] ; Abdullah Zühtü, " Kamus-ul Alam Huzurunda ", Sabah, (3331), 17 Șubat 1314 [1898] ; E(lif) Rasime, "Kamus-i Türki Hakkında ", İkdam, 7-20 Eylül 1316 [19oo] ; Hüseyin Cahit (Yalçın), " Kısa Birkaç Söz ", Servet-i Fünun, 16 (412), 12 Ocak 1314 [1898], pp. 340-343 ; Mefhari, " Kamus-ul Alam ", Sabah, 16 Mart 1315 [1899] ; Ebüzziya Tevfik, " Zamime-i Mecmua-i Ebüzziya ", Mecmua-i Ebüzziya, (80), $1901[1316]$; etc.

22 See for example "Șemseddin Sami Merhum ", Osmanl, (141), 15 Teșrin-i Sani 1904, pp. 10-12, and Abdullah Ch[evdet], "Ch[emseddin] Sami Bey ", Içtihad, (2), Kanun-i Sani 1905 (cited by Hanioğ (M. Șükrü), Osmanlı İttihad ve Terakki Cemiyeti ve Jön Türklük (1889-1902), İstanbul : lletișim, (without date), p. 32, n. 8).

23 İsmail Hakkı (Eldem), Ondördüncü Asrm Muharrirleri, 4. Defter, Semseddin Sami Bey, İstanbul : Kasbar Matbaas1, 1895 [1311]. Sami also launched and took part in intellectual discussions through which he was acknowledged as a self-taught linguist. For these discussions on the language and alphabet reform in the Ottoman press at the turn of the nineteenth century and his earlier but very enthusiastic discussions for the Albanian cause during the first Albanian national movement (1878-1880) (see Levend (Agah Sirm), Șemseddin Sami, Ankara : Türk Dil Kurumu, 1969, pp. 114-142). 
tings of the Turkish intellectuals after Sami's death in $1904^{24}$. In these articles Sami's Albanian nationalism was totally ignored and his intellectual contribution to Turkish culture, especially through his dictionaries and encyclopaedias, were praised. These articles can be seen as the first examples of building Sami's image in Turkish historiography as one of the pioneers of Turkish nationalism. The attitude of seeing Sami as one of the founders of Turkish "cultural nationalism" started to be more common, especially after the rise of Turkish "political nationalism" (Turkism) following the Young Turk Revolution of 1908 during the Second Constitutional era (1908-1918)25.

Sami's image as a Turkish nationalist was consolidated by the writings of the intellectuals in the period of transition from the Ottoman Empire to the new Turkish Republic (1918-1923). An important role in this consolidation was played by one of the pioneers of modern historiography and the last official chronicler (vakainüvis) of the Ottoman Empire, Abdurrahman Șeref ${ }^{26}$. He wrote a serial of popular articles on Ottoman history in the Turkish newspaper Sabah, in 1917 and 1918, and later published them with other articles in a book titled Conversations on History in 1923. As it was popular history with a very wide readership, the position of Sami in these writings might be said to reflect the common image of him in Turkey at that time. The section on Sami in these writings can be found in the chapter on the "Universal Encyclopaedia " (Kamus-ul Alam) of Sami and a "Who's Who of the Ottoman Culture " (Sicil-i Osmani) by another author. The author's evaluation of Sami and his work reads as follows :

we desperately needed such a book. However the late Sami Bey has not prepared it in advance and could not find enough time to search the Oriental sources that he needed, and so could not achieve the necessary research. Due to his hard work and extreme deligence, determination and discpline, he managed to publish this work in such a period when censorship was very dominant and common. (...) The

\footnotetext{
24، Bir Haber-i Elim. Șemseddin Sami Bey'in Irtihali ",Ikdam, 6 Haziran 1320 [19 Haziran 1904] ; Ahmet thsan (Tokgöz), " Ziya-i Elim. Merhum Șemsettin Sami Bey ", Servet-i Fünun, 27 (687), 10 Haziran 1320 [23 Haziran 1904], pp. 162-164 ; " Ziya-i Azim ", Sabah, 6 Haziran 1320 [19 Haziran 1904].

${ }^{25}$ Levend (Agah Sırn), Türk Dilinde Gelișme ve Sadeleșme Evreleri, Ankara : Türk Tarih Kurumu, 1960, p. 219. See for example : Veled Çelebi, "Lisanımızın Esaslan ve Șemseddin Sami Bey ", Resimli Kitap, 1 (4), 1 Eylül 1324 [1908], pp. 24-29 ;Celal Sahir (Erozan), " Lisanumuz - I ", Servet-i Fünun, 37 (951), 13 Agustos 1325 [26 August 1909], pp. 227-230 ; and Ömer Seyfeddin, " Osmanlica Değil, Türkçe n, Türk Sözü, (5), 8 Mayss 1330 [1914], pp. 33-35. In one of the magazines of the Turkism in this period, Genç Kalemler, in March 1912 , Sami, as a "true scholar of language" was given as an example for someone determining the rules of the "new language". (Reprinted in modern Turkish in Parlatır (Ismail), Çetin (Nurullah), Genç Kalemler Dergisi, Ankara : AKDTYK / Türk Dil Kurumu, 1999, p. 404.) In the next issue of this magazine, Sami's article on " Our Language and Literature " was reprinted, to show that the rules for and the revisionist approach towards Turkish that were advocated by this magazine had already been introduced by Sami. (Reprinted in modern Turkish in ibid., pp. 421-426.)
}

${ }^{26}$ See Enver Koray, " Preface ", in Abdurrahman Șeref Efendi, Tarih Muhasebeleri, Ankara : Kültür ve Turizm Bakanhğı, 1985 [1917-1918], p. 3. 
power and knowledge of Sami Bey and his contributions to this country [Turkey] cannot be denied. ${ }^{27}$

\section{Books and articles on Sami28}

Especially after the formation of the Turkish Republic in 1923, the legacy of Sami assumed an important role in the new historiography encouraged by the new regime ${ }^{29}$. His attitude towards the history of the Turkish language and the existing Turkic languages affected all the efforts at rewriting Turkish history following a "Pan-Turkist" approach. Although Panturkism had its roots in the modern historiography of the nineteenth century, it became dominant after the formation of the Turkish Republic with its new capital, Ankara. Being one of the most important leaders of Turkish political nationalism, Yusuf Akçura[oğlu] wrote a very long article on the history of Turkism in the Ottoman Empire in an annual periodical of the Turkist circles, Türk Yull, in $1928^{30}$. In that article, he praises Sami for his contributions to Turkish nationalism in the fields of lexicography, language and history ${ }^{31}$. Akçura also gives a biography of Sami in his article, which was mainly based on the information taken from Sami's son, Ali Sami Yen (an important figure in the history of Turkish football). In this biography Akçura describes Sami's unpublished works on the old Turkish texts as " the most important of works regarding Turkism ${ }^{32}$. This article of Akçura was to be a model for later authors. They also used Sami's children as informants and took his Turkish dictionary and especially his unpublished works on the old Turkish texts as a proof of his being Turkist. This statement of Akçura has been itself used as evidence for recognizing Sami as one of the flag bearers of Turkish nationalism by the majority of subsequent authors and was often quoted 33 . It is also interesting to note here that another intellectual leader of political nationalism, Ziya Gökalp, did not mention Sami among the other pioneers of cultural Turkism listed in the first chapter of his classical book, published in 1923. Although many intellec-

\footnotetext{
${ }^{27}$ Abdurrahman Șeref Efendi, op. cit., p. 273.

${ }^{28} \mathrm{~A}$ thorough and systematic analysis of each of these books and articles will be taken in the later version of this work. Here I will mention every of them and give more information about the content of some. It is here more important to show the common points in these works that served the construction of the myth of a "Turkist Sami".

29 For the "state policy" of the Kemalist regime about history and historiography, see Behar (Büșra Ersanll), İktidar ve Tarih, İstanbul, 1992.

${ }^{30}$ His article in the magazine Turk in 1904 has been accepted as the first manifest for the Turkish political nationalism by scholars.
}

${ }^{31}$ Akçuraoğlu (Yusuf), Türkçülük ve Dı̣̦ Türkler, İstanbul : Toker, 1990 [1928], pp. 82-83.

${ }^{2}$ Ibid., p. 85 .

33 See for example Levend (Agah Sım), Semsedin Sami (op. cit.), p. 151. 
tuals of Sami's time were named as "fathers of Turkism" (i.e. the founders of Turkish cultural nationalism), there is no word about Sami and his works 34 .

In 1928 the Turkish regime had imposed the new Latin alphabet in Turkey instead of the centuries-old Ottoman alphabet (with Arabic script) ${ }^{35}$ and this change was followed by a massive campaign for language reform in the 1930 . This period was seen as the realization of the dream of some modernist intellectuals in the Ottoman Empire, Sami being one of them ${ }^{36}$. This campaign prompted enthusiastic engagement in the project of studying the history of the Turkish language and ended up with the production of a myth that Turkish actually was the mother of all languages. Sami's dictionary of Turkish language was remembered again and used as one of the bases that could be taken as the beginning of reformation ${ }^{37}$. The rising interest in Sami's works and ideas in the 1930 contributed much to the construction of the image of "Turkist Sami" and was accompanied with an impulse to suppress mention of his Albanian nationalism.

It was just at the peak of the language reform movement that a monograph on Sami was published in Turkish by Hikmet Turhan Dağlığlu in 1934, Shemseddin Sami Bey, His Life and Works, which is the first of the five monographs written in Turkish after Sami's death. In his rather non-academic book, the author's main source are the testimonies of Sami's son, Ali Sami (Yen) and the unpublished works of Sami that were in his hands ${ }^{3}$. The prominent Turkish scholar of linguistics and literature, Agah Sirn Levend, published another monograph on Sami in 1969, which was the first scholarly work on Sami39. Together with a long and scholarly written encyclopaedia-entry on Sami by Ömer Faruk Akün in the Turkish version of the Encyclopaedia of Islam,

34 Gökalp (Ziya), Türkçülüğün Esasları, İstanbul : Kültür Bakanlı̆ı, 1976 [1923], pp. 1-11.

35 For a collection of the articles on the question of alphabet reform in the Turkish press of that period see : Yorulmaz (Hüseyin), ed., Tanzimat'tan Cumhuriyet'e Alfabe Tartısmalar, İstanbul : Kitabevi, 1995. For the history of the Turkish "alphabet revolution [reform]" see : Özerdim (Sami N.), Harf Devriminin Öyküsü, Ankara : Ankara Üniversitesi Basımevi, 1962 ; Levend (Agah Sırn), Türk Dilinde Gelișme ve Sadeleșme Evreleri (op. cit.) ; Ülkütașır (M. Șakir), Atatürk ve Harf Devrimi, Ankara : Türk Dil Kurumu, 1981 ; and Șimșix (Bilal N.), Türk Yazı Devrimi, Ankara : Türk Tarih Kurumu Basımevi, 1992.

36 See for example : Va[la]-Nu[rettin], " Akșamdan Akșama : Dil Kurultayı ve Șemseddin Sami ", Akșam, 28 Eylül 1932. For the history of the Turkish language reform in general, see : Levend (Agah Surm), Türk Dilinde Gelișme ve Sadeleșme Evreleri (op. cit.). For collections of the documents and press articles of this period on the language reform see : Korkmaz (Zeynep), Atatürk ve Türk Dili. Belgeler, Ankara : AKDTYK / Türk Dil Kurumu, 1992 ; and Korkmaz (Zeynep), Atatürk ve Türk Dili 2. Atatürk Devri Yazarlarmm Türk Dili Hakkundaki Görüșleri (Gaztelerden Seçmeler), Ankara : AKDTYK / Türk Dil Kurumu, 1997.

37 Levend (Agah Surn), Türk Dilinde Gelișme ve Sadeleșme Evreleri (op. cit.), pp. 407, 422.

${ }^{8}$ Dağhoglu (Hikmet Turhan), Șemsettin Sami Bey Hayatı ve Eserleri, İstanbul : Resimli Ay Matbaası, 1934, P. 9, n. 2.

39 Levend (Agah Sum), Șemsedin Sami (op. cit.). 
which was published one year earlier, Levend's book has served as the only reliable Turkish source for years. The third monograph, written by Ethem Çalık, was on Sami and his work Civilisation of Islam, the whole text of which was printed as a part of the book. The fourth book is titled Shemseddin Sami, his life, art and works ; however, the author has hardly anything to say about Sami's life or works $4^{\circ}$. After a very short (two and a half pages!) section on Sami's " art and character ", the next two chapters are taken from other authors without any precise bibliographical information ${ }^{41}$. The rest of the book contains a full text of the only novel written by Sami, which constitutes the major part of the book. The fifth and last book $\mathbf{4}^{2}$ published in Turkish on Sami is a popular study which repeats the information in the first three books and in the article of Akün, all mentioned above. Apart from Dağlıoglu's book, all other books include a section of selections from Sami's works 43 .

A thorough and systematic analysis of each work is not possible in the scope of this paper, but some general observations on the evaluation of Sami in these books can be summarized as follows. The common point in these works is the contribution to the myth of a Turkish intellectual who devoted his life to the Turkish cause through his studies on Turkish language. Dağloğlu, for example, states at the beginning of his book : " it can be said that Šemsettin Sami Bey, who is a true son of this country [Turkey], spent his whole life studying the Turkish language and died while working on it "44. In the first part of the book about Sami's life, family and character, his activities during the formation of Albanian intellectual associations and his engagements against the annexation of some parts of Albania in the newspaper, Tercüman$I$ Șark, and his active support for the Albanian nationalist movement, such as fighting against annexation plans between 1878-1881, are not mentioned. In the second part of his book, which is about Sami's works, none of his works in Albanian or about the Albanian language is named. The rest of the book is devoted to the analysis of Sami's published and unpublished works on the old Turkish texts that have been viewed by Turkish intellectuals as evidence of Turkism. After giving a small piece of Sami's unpublished work on Orhon Abideleri, the author adds : " this work is very important from the point of Turkism "45. Dağlıoglu also provides the " Preface " from another unpublis-

40 Yerguz (İsmail), Șemsettin Sami, Yaşamı, Sanatı, Yapıtları, İstanbul : Engin Yayıncılık, 1997.

${ }^{41}$ One is from Kudret (Cevdet), Abdülhamit Devrinde Sansür, İstanbul : Milliyet, 1977 ; and the other from Levend (Agah Sirm), Semsedin Sami (op. cit.).

42 Tural (Șecaattin), Șemsettin Sami, İstanbul : Șule, 1999.

43 Below I will discuss the content of these selections to expose the selective perception of the authors.

44 Dağloğu (Hikmet Turhan), op. cit., p. 4.

45 Ibid., p. 42. 
hed work of Sami, the analysis of which, according to the author, "would prove to what extent he served Turkishness $" 46$. In the "Conclusion ", the author states that Sami's " most important contribution was the one to the Turkish language, therefore to Turkism $" 47$.

This total neglect of the Albanian side of Sami cannot be seen in the serious monograph written by Agah Sirr Levend in 1969, but he also contributes to the myth of Sami as the "Turkish" intellectual. Levend had already glorified Sami's contribution to the language reform in the Ottoman Empire in his unique book on the history of the language reform, cited above ${ }^{8}$. Being ideologically less biased than earlier books and articles on Sami, Levend's work on Sami is rather a descriptive study on Sami's life, works and ideas. However, his contribution to the mythologization comes out especially when he writes about the discussion in the Turkish press of the 1940s about Sami's only political book in Albanian, Shqipëria - Ç'ka qënë, ç'është e çdo të bëhetë (Albania What it was, what it is and what it will become). The book was published for the first time in Bucharest in 1899 without the name of the author on it and it has been seen as a manifesto for political nationalism in Albania49. The book includes criticism of the modern Ottoman regime and advocates an independent Albania.

After transmitting the discussion in the Turkish press about this book, Levend concludes that it cannot belong to Sami. Levend devotes few pages of his book to the writings of Sami in the Turkish press in 1878 and 1879 supporting the national resistance of the Albanians. He denies the fact that Sami worked for the secret Albanian association founded in 1880 in Istanbul. Besides this, he states that Sami did work for the "Albanian Scientific Association " (Cemiyet-i Ilmiye-i Arnavudiye), which was established in 1879 under the control of Sultan ${ }^{50}$. However, while discussing the claims that Sami wrote the book in question, the author concludes that "Sami's character, works and ideas that he often expressed in his writings declare these claims to be untrue " 51 . In his "Conclusion ", Levend reminds his readers of the fact that Sami, with more than his fifty works, served Turkish culture until the end of his life. He also informs us about some Albanian works of Sami on the Albanian language and alphabet. It is obvious that Sami is seen as one of the pioneers of

46 Ibid., p. 43 .

47 Ibid., p. 59.

$4^{8}$ Levend (Agah Sım), Türk Dilinde Gelișme ve Sadeleşme Evreleri (op. cit.), pp. 130-134 \& passim.

49 For this discussion see below.

${ }^{50}$ Levend (Agah Sum), semsedin Sami (op. cit.), pp. 114-120, 146, 148.

s1 Ibid., p. 148. 
Albanian nationalism because of these works, though Levend deals with this "problem" as follows :

in the meantime he did not forget the people of his own race. It is the right and duty of everyone to think for and try to be useful to his/her race. Sami fulfilled this mission by preparing his books "Albanian Alphabet" and "Albanian Grammar". (...) Sami became useful to the people from his race in this context. (...)

However, above this service, he was devoted to Ottomanness, tried to be useful in fact to Turkishness, through the works that he published one after another. ${ }^{22}$

Like other Turkish authors of the books on Sami written before and after the publication of his book, Levend also uses the fact that Sami had been studying some old Turkish texts as proof of his complete devotion to Turkism : " in the last years of his life Sami devoted himself completely to Turkishness. What a devotion it is to work on books like Kutadgu Bilig, Orhon Abideleri, Et Tuhfetü'z-Zekiyye, Lehçe-i Türkiyye-i Memalik-i Msır, which were known by few people in those days "53.

Another common argument that Levend shares with other Turkish authors is the assumption of being able to discover a single determinant attitude in Sami's writings in support of the thesis that the language of the Turks is not "Ottoman" but "Turkish". As classic evidence of this attitude, Sami's "preface " to his monolingual Turkish Dictionary and his article published in his own magazine Hafta (The Week) in 1880 have been referred to by Levend and other authors. As will be seen below, there are also many Turkish "selections" of Sami's writings and general Turkish anthologies where Sami's works find a place 54 .

The last words in Levend's conclusion are quite striking, as they show the argument to be an indirect polemic with the author's Albanian collocutors : " no other attribute than "Turk" can be given to Sami. Nobody can take this quality from him and his family " 55 .

The last claim of Levend is very important because he correctly indicates a crucial aspect of Sami's writing as evidence. Sami does use expressions like "We are neither Arab nor Persian ; we are original Turks "56.

The author of the next Turkish book in question, Ethem Callk is a scholar who wrote an M.A. thesis on Sami. His book contains three main parts : first, one on Sami and his works and ideas, secondly, a full text of Sami's book,

52 Ibid., p. 150.

53 Ibid., pp. 150-151.

54 For the reprint of the "preface" see :Ibid., Pp. 172-185, and for the article mentioned, see : Ibid., pp. 152157.

55 Ibid., p. 151

${ }^{56} \mathrm{Ibid}$. 
Civilisation of Islam, and finally the selections from Sami. Starting from the last part, it can be seen that almost the same texts as those in Levend's book, which demonstrate the devotion of Sami to "Turkishness" and Turkism are chosen 57 . From Sami's opus magnum, "Universal Encyclopaedia " (Kamus-ul Alam), Çalık chooses the entries "Turk", "Turan" and "Turaniye" for this selection ${ }^{58}$.

In the first part of his book, Çalık reproduces the same mythologization discourse, discussing Sami's " national ideas on the Turkish language " and remarking in a separate chapter : "Sami made for himself a great position in the history of Turkishness through his ideas and works "59. Then he concludes with a quotation from Sami without any reference : " there is no doubt that our national language Turkish is one of the best languages of the world, if not the best "6o. Çalık devotes a chapter to Sami's Albanian Nationalism, where he mentions Sami's activities for the protection of the rights of Albanians during the discussions on the Eastern Question, his contributions to the Albanian language and the alphabet reform. He differs from Levend by recognising that the much-discussed political book, Albania - What it was, what it is and what it will become, was written by Sami himself ${ }^{61}$. Çalık summarizes the discussions about this book in the Turkish press, as stated in Levend's book.

In the conclusion of his book, Çallk, just like Levend, uses Sami's engagement in working on old Turkish texts as proof of the fact that Sami was one of the first Turkish experts on the Turkish language. He concludes :

though Sami used expressions like "our fellow-people, our ancestors" for the Turks of Central Asia ; "our national language, our mother tongue" for Turkish, and then [wrote] "we are neither Arab nor Persian", he did not hesitate to blame the Turkish nation in some respects, and to write the book Albania - What it was, what it is and what it will become for his nation, which was the foundation of his other ideas. ${ }^{62}$

The fourth book to mention here cannot be regarded as a serious study ${ }^{63}$. It nevertheless reveals much about the place of Sami in the popular Turkish historiography and is an example of a certain type of nationalistic popular history widespread in Turkey. In the very short chapter at the beginning of the

57 Çaluk (Etem), Șemseddin Sami ve Medeniyet-i İslamiyye, İstanbul : İnsan, 1996, pp. 87-139.

${ }^{5}$ Ibid., pp. 100-104, 104-106, 106-111.

59 Ibid., pp. 79-85.

60 Ibid., p. 85 .

${ }^{61}$ Ibid., p. 70.

${ }^{62}$ Ibid., p. 204.

63 Yerguz (Issmail), op. cit. 
book, which is the only part written by the author himself, Sami and his works are glorified and his Albanian side is not even mentioned 64 .

The most recent book on Sami in Turkish was published in 1999 by Șecaatin Tural, a school-teacher in Istanbul ${ }^{65}$. The book consists of two parts : one on the Sami's life and works, and the other consisting of selections from his writings. In the first part, Tural states that Sami was " one of the members of the Albanian association of "Albanian Scientific Association", which was founded in 1879 ", and that he wrote the books Albanian Alphabet and The Grammar of Albanian. The author claims that " these two books caused Sami to be accused (!) of being an Albanian nationalist "66. In summary, Tural does not differ from other authors when he sees him as " one of the prominent people of the Turkism movement ", and when he refers to the usually cited evidence of Sami's Turkism : the "preface " of Sami's monolingual Turkish Dictionary and his article, " (Ottoman) Turkish Language " published in Hafta in $1880^{67}$. Different from other authors, who tend to see Sami rather as a Turkist in terms of "cultural nationalism", Tural shows Sami as a "Turkist" in terms of "political nationalism" as well :

Shemseddin Sami's claim that the unification of the eastern and western Turkish languages would also create the basis for political unification is very important because it shows his contribution to the idea of Turkism. The entries "Turk" and "Turan" that he wrote in "Universal Encyclopaedia " (Kamus-ul Alam) show also that geographically he does not regard "Turkishness" as consisting of only the Ottoman lands. Advocating the idea that Turkish language and literature already began in Central Asia, Sami worked on Kutadgu Bilig and Orhon Abideleri, aimed at making them known to Turkish readers, and suggested that Kudadgu Bilig should be read in schools. ${ }^{68}$

Apart from these monographs, there is an encyclopaedia entry on Sami that differs from other ones cited above and has greater scope and a more scholarly approach $^{69}$. This twelve-page entry by Ömer Faruk Akün, published in the Turkish version of the Encyclopaedia of Islam in 1968 has been the most cited source on Sami. It is one of the most informative sources in Turkish and includes mention of Sami's activities in favour of the Albanian resistance during 1878-1881. However,

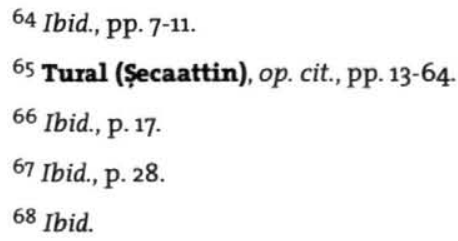

69 Akün (Ömer Faruk), " Șemsettin Sami ", İslam Ansiklopedisi, Eskișehir : Anadolu Üniversitesi Güzel Sanatlar Fakültesi, 11, 1997 [1968], pp. 410-422. 
even Akün finds it necessary to note that Sami was against the separation of Albania from the Ottoman Empire, and that he only fought against the annexation of some parts of the Albanian territories by the expansionist neighbouring countries. He also does not omit the detail that the "Albanian Scientific Association" in Istanbul was founded with the permission of the Sultan. The author mentions also Sami's works on the new Albanian alphabet, and records his much discussed book, Albania - What it was, what it is and what it will become, without giving any information about the content ${ }^{70}$. The rest of his text is devoted to Sami's contribution to Turkish intellectual life and " his nationalist ideas on Turkish and literature ", where Sami's "Turkist mentality" is emphasized and his activities as an Albanian intellectual after 1881 are once more sidelined.

Indeed, this total neglect of Sami's activities as an Albanian intellectual, after the suppression of the first Albanian national resistance in 1880-1881 by the Sultan, is without exception a feature of all Turkish history books and articles. As it will be shown below, this has resulted in a total ignorance among Turkish historians of the details of Sami's participation, as one of the publishers and an author, in the publication of the first Albanian periodical in Istanbul, from August 1884 on Drita (later Dituria).

Besides works written exclusively on Sami, the construction of the image of Sami as a "Turkist" has also been reinforced by academic and popular books and articles in Turkey dealing with the general history of the (modern) Ottoman Empire ${ }^{71}$. Books and academic articles on the modern history of Ottoman literature ${ }^{72}$, the Ottoman press and publishing 73 , the Ottoman thea$\mathrm{tre}^{74}$, the history of the Turkish language and alphabet reform 75 , and on the in-

$7^{\circ}$ Ibid., p. 412.

7 As a representative example of the mainstream Turkish historiography see : Karal (Enver Ziya), Birinci Meşrutiyet ve İtibdat Devirleri (1876-1907), Ankara : Türk Tarih Kurumu Basımevi, 8, 1995.

72 Tanpınar (Ahmet Hamdi), Edebiyat Üzerine Makaleler, İstanbul : MEB, 1969 [1997] ; Enginün (tnci), Yeni Türk Edebiyatı Araștırmaları İstanbul : Dergah, 1991 ; Has-Er (Metin), Tanzimat Devri Türk Romanunda Kadm Kahramanlar, Ankara : Atatürk Küłtür Merkezi Bașkanlı̆g, 2000 ; Banarh (Nihad Sami), Resimli Türk Edebiyat Tarihi, 2 vols., Ankara : Milli Eğtim Basımevi, 1998 ; Kaplan (Mehmet), Türk Edebiyatı Üzerinde Araştormalar 2, İstanbul : Dergah, 1999 ; Esen (Nüket), Türk Romanznda Aile Kurumu (1870-1970), Istanbul : Boğaziçi Üniversitesi Matbaası, 1990 ; and Ismall Habib, Edebi Yeniliğimiz 2, İstanbul : Devlet Matbaası, 1930-1932.

73 Selim Nüzhet [Gerçek], Türk Gazeteciliği, İstanbù : Devlet Matbaası, 1931 ; and Őzdem (Rag̊p), « Tanzimattan Beri Yazı Dilimiz. Fikri Nesir Dilimizin Gelișmesi. (Gazete, Mecrnua ve Tamimi Kitap Dili) ", in Tanzimat. 100. Yldönümü Münasebetiyle, Istanbul : Maarif Matbaası, 1940.

74 Sevengil (R. Ahmet), Türk Tiyatrosu Tarihi, Meșnutiyet Tìyatrosu, Istanbul : Milli Eg̈itim Bakanliğ, 4, 1962 ; Alu (Niyazi), XIX. Yüzyl Türk Tiyatro Tarihi, Istanbul, 1963 ; Menemenciogu (Nermin), "The Ottoman Theatre 1839-1923 ", Bulletin, 10 (1), 1983, pp. 48-58.

75 Levend (Agah Sum), Türk Dilinde Gelișme ve Sadeleșme Evreleri fop. cit.) ; Onkitạur (M. Saldr), op. cit. ; Șimșir (Bilal N.), op. cit. ; Korlmaz (Zeynep), Dil İkulabmun Sadeleșme ve Türkçeleșme Akmlan Arasmdaki Yeri, Ankara : Türk Tarih Kunumu Basımevi, 1985 ; and Dizdarog̈n (Hilmet), ed., Dilcilere Saygı, Ankara : Türk Dil Kunumu, 1966. 
tellectual history of the modern Ottoman Empire ${ }^{76}$ have played as important a role as the monographs on Sami.

The content of these works cannot be discussed here. However, in summary, it can be said that the mythologization in Turkish historiography is repeated in these books. An exception among such works is the book of Bilal Şimșir who informs his readers of Sami's active participation in Albanian cultural nationalism through his contribution to the Albanian alphabet reform movement of the "Albanian Scientific Association" in Istanbul77.

In the memoirs of Turkish intellectuals Sami was always mentioned and praised for his role in the history of the Turkish press, the important place of his French dictionary ${ }^{78}$, and his influence on other intellectuals through his plays and translations 79 .

In summary, praise of Sami in Turkish historiography as one of the leaders of Turkish cultural nationalism was not only based on his precious lexicographical works, but also on his approach towards the Turkic language(s) and towards "Turkishness" in general, which could be seen in the prefaces of his books and articles in the press. Apart from these writings of his, the fact that in his last years he had been working on old Turkish texts to prepare them for publication and that he had close relations with the (oppositional) Turkist circles of his time was used to prove his devotion to Turkism.

\section{SAMI FRASHËRI : SAMI IN THE ALBANIAN HISTORIOGRAPHY}

Regarding the myth(ologization) of Sami as the "ideologue of Albanian nationalism" or as "one of the founders of Albanian nationalism" in its most compact form in current Albanian culture and average historiography, again (1) school text books and (2) encyclopaedia-entries can be used. As I did in the case of the Turkish mythologization, I will here use only latter group, because so far I have been able to study them.

${ }^{76}$ Mardin (Șerif), Yeni Osmanl Düșüncesinin Dağușu, İstanbul : hletișim, 1996 ; Mardin (Şerif), Jön Türklerin Siyasi Fikirleri 1895-1908, İstanbul : M̀etișim, 2000 ; and Uhlken (Hilmi 2iya), Türkiye'de Çağdaș Düşünce Tarihi, Istanbul : Ülken, 1992.

7 șimșir (Bilal N.), op. cit., p. 41. Interestingly, the author does not mention Sami's influence on Turkish alphabet reform movement in the later years.

$7^{8}$ Ahmed Rasim, Matbuat Hatralarmdan, Muharrir, Șair, Edib, İstanbul : Tercüman, 1001 (141), 1980 [1924]. p. 49 ; Tokgöz (Ahmet thsan), Matbuat Hatzalarım, İstanbul : İetișim, 1993, P. 34 ; and Tanpunar (Ahmet Hamdi), op. cit., p. 577 .

79 Ahmed Rasim, op. cit, pp. 16 (n. 1), 76-77 ; Abdülhak Hamid, Abdülhak Hamid'in Hatmlan, Istanbul : Dergah, 1994. 
In the official and largest encyclopaedia of socialist Albania ${ }^{80}$, which is only one volume consisting of 1245 pages, Sami is introduced by Shaban Çollaku as the " main ideologue of the Albanian National Movement " ${ }^{81}$. Such an identification of Sami is due to the 1899 book mentioned several times above. The author describes Sami as a productive author of literary and didactic books, translator and journalist. His ideas on the Albanian question of his time and his participation in the nationalist movement are emphasized. The fact that he sometimes called himself "Turk" and used the expressions like "our language" for Turkish, and "our race" for Turkic people, is totally ignored.

The same attitude and a similar description can be found in the entry on Sami in the Dictionary of Philosophy published in 1974 : " distinguished thinker, great ideologist and one of the organizers and leaders of the patriotic and cultural movement of Albanian Renaissance at the end of the nineteenth century " 82 . After discussing his "progressive" philosophy, the entry finishes with the evaluation of Sami as " an ardent patriot, an unyielding fighter for the independence of Albanian people ", which is based on his book Albania : what it was, what it is and what it will become.

In a Dictionary of Pedagogy published in 1983, the entry on Sami begins with exactly the same sentences as those of the previous dictionary ${ }^{83}$. Here, mainly Albanian works of Sami are mentioned and the major part of the entry is devoted to Sami's ideas in his abovementioned book. Afterwards, while giving information on the role of Sami " as a pedagogue ", his positive influence on the struggle of independence of Albania is praised.

Another interesting example of this mythologization can be found in a Lexicon of the Albanian Writers for Children (1872-1995) published in 1997. There Sami is introduced as follows : " Sami Frashëri was a person of ideas and deeds. He was one of the most prominent and significant personalities of our national renaissance. All his activities are important, but the one that takes the special place is the effort of this distinguished patriot for a common alphabet for Albanian language ${ }^{84}$.

\footnotetext{
${ }^{80}$ Buda (Aleks), Uçi (Alfred), Dodi (Anastas), eds., Fjalor enciklopedik shqiptar, Tiranë : Akad. e Shkencave e RPSSH, 1985.

${ }^{81}$ Çollaku (Shaban), " Frashëri, Sami (1850-1904) ", in Buda (Aleks), Uçi (Alfred), Dodi (Anastas), eds., op. cit., p. 290.

${ }^{82}$ Pëllumbi (Servet), Spahiu (Fiqret), Fjalor i Filozofisë, Tiranë : 8 Nëntori, 1974, p. 108.

83 Osmani (Shefik), Fjalor $i$ Pedagogjise, Tiranë : 8 Nëntori, 1983.

84 Grillo (Odhise), Lexikon Shkrimtarët Shqiptar per Fëmijë (1872-1995), Tiranë : Botimet Enciklopedike, 1997, p. 64.
} 


\section{The construction of the myth}

The history of this myth-making can be traced in much older books and articles on Sami in Albanian.

Indeed, Sami was already an important figure for the Albanian nationalist intellectuals of his time. His books and articles were published by the Albanian publishing houses in Bucharest and Sofia, and periodicals in different countries under the pseudonym of S.H.F. In the Albanian newspaper Drita (Light) published in 1885-1985 in Istanbul, the name of which was changed into Dituria (Knowledge) after the third issue, Sami signed his articles with three stars ${ }^{85}$.

Apart from his books in Albanian published in Bucharest, an Albanian translation of his play Besa was published by A. Kolonja in Sofia already in $1901^{86}$ and discussed in the Albanian press of that time and later ${ }^{87}$. Since the subject of this drama was Albania, it was published several times in Albanian ${ }^{88}$. Another work of Sami that attracted the attention of the Albanian press of that time was his Albania - What it was, what it is and what it will become. There were discussions about this book in the Albanian press as early as in year 1900. For example, one of the famous Albanian nationalist intellectuals, L. Gurakuqi, wrote a review on this book in La Nazione Albenese, 31 March 1900. The interest in the Albanian press for this book continued in later years with its reprint and translation into different languages ${ }^{89}$.

Sami's activities and works were followed very closely and he was praised for them as a nationalist Albanian intellectual by the Albanian periodicals of his time ${ }^{90}$. His death was reported with a great sorrow by these periodicals ${ }^{91}$.

\footnotetext{
85 It was published as an organ of the "Association of Publishing of Albanian Writings" (founded in 1879) and printed in "Istanbul alphabet" that was developed by Sami himself. See : Kondo (Ahmet), "Kontributi i Revistës "Drita-Dituria", për Përhpjen e Ideve Kombëtare dhe të Njohurive Shkencore ", Studime Historike, (3), 1970 ; Kondo (Ahmet), « Drita »-« Dituria »(1884-1885), Tiranë : Shtepia Bot. i Librit Politik, 1972 ; Dilaver (Sadikaj), " A. Kondo: "Drita"-“Dituria” (1884-1885) ", Studime Historike, (1), 1974 ; and Fshazi (Falma), "İstanbul'da Illk Arnavutça Dergi : "Drita" ve "Dituria", (Osmanlı'da bir Arnavutça Derginin Maceras1) ", Mütefferrika, (21), 2002. As mentioned above, Sami's role in the publication of this newspaper, and his articles there are neglected in the Turkish historiography.
}

${ }^{86}$ Frashëri (Sami Bey), Besa, Drame me ghashte pamje, prej Sami Bej Frashërit, Shqiperuar nga Turqishtja prej Ab. A. Ypi Kolonja, Sofia : Mbrothesia, 1901.

${ }^{87}$ For some examples see : Toska, (2), October 1901, p. 13 ; Koha, 21 April 1921, p. 4 ; Dielli e flamuri, 13 January 1911, p. 4 ; and Dielli, 15 February 1912, p. 3 (all cited by Jorgaqi (Nasho), " Bibliografi për Letërsinë Shqipatre të Rilindjes Kombëtarë (1836-1977) n, Studime Per Letersine Shqiptare I. Probleme të letersise shqiptare të Rilindjes Kombëtare, Tiranë : Akademia e Shkencave e Rps të Shqiperisë, Instituti i Gjuhësisë dhe i Letërsisë, 1981, pp. 628-629).

88 For the list of these publications see : Bakiu (Zyber Hasan), kruja, Bibliographi e zgjeruar e veprare të Sami Frashërit, Tiranë : Shtepia Botuese 8 Nentori, 1982, pp. 139-140.

89 See : La Nazione Alabanese, 15 April 1905 ; and Drita, 15 October and 15 November 1907.

90 For some examples see : La Nazione Alabanese, 30 May 1899, p. 8 ; and 31 March 1900, pp.-5-6.

$9^{1}$ See : La Nazione Alabanese, 30 June 1904 and 15 July 1904 (by L. Gurakuqi) ; Drita, 14 June 1904 ; and Kalendari Kombiar, 1905, pp. 30-31. 
In the context of being praised by the nationalist Albanian intellectuals, however, Sami was in the shadow of his two elder brothers, the eldest of which, Abdyl, was the leader of the first political movement of the nationalists in Albania ${ }^{92}$. Being one of them, Faik Konitza, for instance, wrote in an unpublished Essay on the Albanian National Movement in 1899 that Sami was " the brother of Naim, but less patriotic than him. He published a grammar of Albanian "93. This is an important piece of information that reveals that the mythologization of Sami as the "ideologue" of Albanian nationalism must have developed after his death. Sami actually worked in a rather more secret and indirect way, given the conditions he was living under in the capital city of the Empire. His close relation with the modernist Ottoman intellectuals and his engagement in their press made some people believe that he was not much interested in the Albanian nationalist movement. Besides, because of the heavy pressure of the Abdulhamidian regime on any oppositional activity and its undoubted surveillance of Sami's activities, he could not have worked as openly as the other intellectuals in those other centres of the Albanian diaspora, Sofia, Athens, Bucharest, Brussels, Rome, etc. 94 It was known by the Albanian intellectuals of that time that he used his relations in Istanbul to help the nationalist Albanians set up an Albanian school in Korça, Albania in $1887^{95}$.

92 Both Abdyl and the other brother, Naim, who was an active participant of the later struggle of the Albanian intellectuals for cultural nationalism, were very much praised by the people in Albania and by the intellectuals in diaspora.

93 Sadiku (Riza), Hasan Kaleshi Jeta dhe Vepra, Shkup : Focus, 1996, p. 234. (" Këshiltar i shtetiti i vëllai i Naimit, por më pak patriot se ky i fundit. Ka botuar një gramatikë shqipe. n)

94 For the activities of Albanian nationalists in diaspora see : Teuta (Hoxha), Nuro (Kujtim), Nika (Arta), Bubsi (Almira), Shoqëritë Patriotike Shqiptare Jashtë Atdheut për Arsimin e Kulturën Kombëtare 1879-1912, Tiranë : 8 Nëntori (without date) ; Dodani (Vissar), Memoriet e Mija. Kujtime Nga Shvillimet e Para e Rilindjes të Kombit Shqipetar Nde Bukuresht, Albania : Constantza, 1930 ; Maksutovici (Gelku), " Kontribute të Reja për Njohjen e Shtypit shqiptar në Rumani ", Gjurmime albanologjike, Seria e shkencave historike, 1, 1971 ; Bala (Vehbi), " Lidhjet Kulturore Shqiptare - Rumune ", Buletini shkencor $i$ universitetit të larte pedagogjik, Numer i Pojaçem, 1964 ; Bala (Vehbi), "Shtypi shqiptar ne Rumani ", Rev. Shkenc. Inst. Pedag. Dyvjeç. Shkode, 1, 1964 ; Dërmaku (Ismet), " Mbi Veprimtarinë Politike-Kulturale të Shqiptarëvet në Rumani Gjatë Rillindjes Shqiptare ", Vjetar i Arkivit të Kosovës, 2-3, 1966-1967 [1970] ; Dërmaku (Ismet), "Veprimtaira Kulturo-Arsimore dhe Patriotike e Kolonisë Shqiptare në Konstancë (Rumani) në Fund të Shek, XIX dhe në Fillim të Shek, XX. Shkolla Fillore Shqipe "Drita, (1905-1908)" dhe Rëndësia e Saj n, Vjetar $i$ arkivit të Kosovës, 1983 ; Dërmaku (Ismet), " Disa Dokumente Përkitazi Me Aktivitetin e Shoqërive ,Drita' dhe „Dituria' të Bukureshtit 1886-1896 ", Vjetar i Arkivit të Kosovës, 18-19, 1982-1983 [1984] ; Sokollova (Bojka), « Roli i Kolonisë Shqiptare të Sofjes për Zhvillimin e Letersisë shqipe në Kohën e Rilindjes ", Seminari mbi kulturën shqiptare për të huaj, 4, 1978 ; Abdyli (Ramiz), " Dr. Ismet Dermaku : Rilindja Kombëtare Shqiptare dhe Kolonitë Shqiptare të Mërgimit në Rumani dhe në Bullgari, Enti i Mjeteve dhe i Teksteve shkollore të KSA të Kosovës, Prishtinë, 1983, 457 n, Vjetar i Arkivit të Kosovës, 18-19, 1982-1983 [1984] ; and Bylykbashi (Ymer), " Nga Fondi i Periodikut të Arkivit të Kosovës Gazeta e Perdyjavshme ,Drita' e Sofjes ", Vjetar i Arkivit të Kosovës, 16-17, 1980-1981 [1983].

95 See for example Sadiku (Riza), op. cit., p. 214. 
The construction and spread of the myth of Sami as a progressive and nationalist Albanian leader have been reinforced by the academic and popular books and articles in Albania dealing with the general history of modern Albania ${ }^{96}$. In order to trace this process, (1) the historiography on Albanian education ${ }^{97}$ must be also studied, because of his role in the struggle for education in the Albanian language, besides (2) the Albanian historiography on the alphabet and language reform ${ }^{98}$, (3) Albanian nationalist discourse ${ }^{99},(4)$ press and publishing ${ }^{100}$, (5) Albanian theatre and (6) Albanian literature ${ }^{101}$. I have not finished the study of these sources and it is anyway impossible to discuss the place of Sami in each of these groups of sources separately in this paper. However, I can say, according to my research so far, that these books and articles contributed to the myth of Sami as a "progressive ideologue of Albanian nationalism". It can be added that many documents unknown to the Turkish

96 As representative examples of the mainstream Albanian historiography see : Pollo (Stefanaq), et al., Historia e Shqipërisë, vëllime II (Vitet zo të shek. XIX-1912), Tiranë : Akad. e Shkencave e RPS të Shqiperise / Inst. i Historise, 1984. See also Frashëri (Kristo), The History of Albania (A Brief History). Tirana, 1964; and Puto (Arben), Pollo (Stefanaq), The History of Albania. From its Origins to Present Day, London : Routledge / Kegan Paul, 1981.

97 Myzyri (Hysni), Shkollat e Para Kombetare Shqipe (1887- korrik 1908), Tiranë : 8 Nentori, 1978 ; Myzyri (Hysni), Mësonjëtorja e Parë Shqipe e Korçes, Tiranë : Shtëpia Botuese e Librit Shkollor (Institutit ë Studimeve Pedagogjike), 1987 ; and 100 Vjetori i Mësonjëtores së Parë Shqipe të Korçës, 7 Mars 1887-1987, Tiranë : Instituti i Studimeve Pedagogjike, 1987.

$9^{8}$ Buda (A.), Domi (M.), Polo (S.), Prifti (K.), Samara (M.), Alfabeti i Gjuhes Shqip dhe Kongresi i Manastirit, Tiranë, 1972 ; Osmani (Tomor), Udha e Shkronjave shqipe, Histori e alfabetit, Shkodër : Universiteti i Shkodrës " Luigj Gurakuqi " Sektori Shkencor i Albanologjisë, 1999 ; Hoxha (Ibrahim D.), Nëpër Udhën e Penës Shqiptare, Nga Historiku i ABC-së dhe i Shkrimit Shqip, Tiranë : Shtëpia Botuese e Librit Shkollor (Institutit ë Studimeve Pedagogjike), 1986; and Jahaj (Idajet), Kur Çelnin Shkronjat, Tiranë : Botimet Toena, 2000 .

99 Shpuza (Gazmend), “ Vëllezërit Frashëri në Prag të Lidhjes Shqiptare të Prizrenit ", Nentori, (6), 1968 ; Xoxi (Koli), Lidhja Shqiptare e Prizrenit, Tiranë, 1978 ; Frashëri (Kristo), Lidhja e Prizrendit, Tiranë, 1956 ; Frashëri (Kristo), Rilindja Kombetare Shqipatre. Me rastin 50 vjetorit të shpalljes se Pavaresise Kombetare 1912- 28 Nendor -1962, Tiranë : Naim Frashëri, 1962 ; Prifti (Kristaq), Lidhja Shqiptare e Pejes. Levizja kombetare 1896-19oo, Tiranë : Akad. e Shkencave e RPS të Shqiperise (Inst. i Historise), 1984 ; and Pollo (Stefanaq), Në Gjurme të Historise Shqiptare 1, Tiranë : Akedemia e Shkencave e RPS të Shqiperise (Instituti i Historise), 1990.

100 Zelka (Iuan), Në Mbrojtje të Kombit, Tiranë : Botimet Toena, 1999 ; Fshazi (Falma), art. cit. : Maksutovici (Gelku), art. cit. ; Daka (Palok), " Bibliografi Retrospektive e Shtypit Periodik Shqiptar e Mbi Shqipërine e Viteve 1848-1944 (I. 1848-1908) ". Studime Historike, (3). 1971; and Daka (Palok), " Bibliografi Retrospektive e Shtypit Periodik Shqiptar e Mbi Shqipërine e Viteve 1848-1944 (II. 1909-1919) ", Studime Historike, (4), 1971.

${ }^{101}$ Samara (Miço), Formimi i Gjuhes Letrare Kombetare Shqipe, Tiranë : Shtepia Botuese Librit Universitar, 1989 ; Bihiku (Koço), A History of Albanian Literature, Tirana : 8 Nentori, 1980 ; Qosja (Rexhep). Historia e Letërsisë shqipe Romantizmi, Tiranë : Botime Toena, 2000 ; and Shuteriqi (Dhimiter S.), Bihiku (Koco), Domi (Mahir), Bala (Vehbi), Kodra (Zinudin), Sako (Zihni), Historia e Letërsisë Shqipe Il, Letersia Shqip e Rilindjes Kombitare, Tiranẽ : Instituti i Historise dhe i Gjuhesise, 1960. 
historiography and providing arguments for this mythologization were used in these sources and published in the separate volumes ${ }^{102}$.

\section{Books and articles on Sami}

The most important role in the process of making the myth of Sami as "a progressive ideologue of Albanian nationalism" has been played by the academic articles and monographs (directly) on Sami, which I am going to discuss here.

There are four Albanian monographs and one extensive bibliographical book on Sami and his works. Two of these monographs were written by E. Reso. His later book, published in $1980^{103}$, is the extended and modified version of the first one published in $1962^{104}$. For this reason it would be reasonable to discuss these books together. Neither of them provides an historical account of Sami's life and his time. The author informs his readers about Sami's life and his time in a very short chapter at the beginning of the book drawing on secondary sources. Sami's activities both in Albanian and Turkish life are summarized. The first book starts with the precise description of the mythologization of Sami in Albania : "Sami Frashëri - the ideologue of our national movement in the nineteenth century- lived and worked under the conditions of the feudal-military Turkish empire ${ }^{105}$. There is hardly any contribution to the life history of Sami. The author devotes the major part of his book to the "Philosophical, Sociological and Political Opinions" of Sami, as it is promised in the title of both books. The books of Sami are discussed in two parts : his "philosophical opinions", and his "social and political opinions". Each of these parts is divided into chapters like "Sami on the indispensability of science and its links with practice", "Sami on warmth", "Sami on light and colours", etc., where

102 Pollo (Stefanaq), Pulaha (Selami), eds., Akte të Rilindjes Kombëtare Shqiptare, 1878-1912 (Memorendume, vendime, protesta, thirrje), Tiranë : Akedemia e Shkenceve e RPS të Shqipërise, Instituti Historisë, 1978 ; Prifti (Kristaq), ed., Lidhja Shqiptare e prizrenit ne Dokumentete osmane 1878-1881, Tiranë : akad. e Shkencave e RPS të Shqiperise (Inst. i Historise), 1978 ; Haskaj (Zihni), ed., Mendimi politik e shoqeroro $i$ Rilindjes kombetare shqiptare. (Permbledhje artikujsh nga shtypi), vol. 1, Tiranë : Univ. i Tiranes, Inst. i Historise dhe i Gjuhesise, 1971 ; Mile (Ligor), ed., Shqiperia ne vitet e Lidhjes Shqiptare të Prizrenit, (Dokumente arkivash franceze), vol. 1, Tiranë : Akad. e Shkencave e RPS të Shqiperise (Inst. i Historise), 1978 ; Mile (Ligor), ed., Shqiperia ne vitet e Lidhjes Shqiptare të Prizrenit, (Dokumente arkivash franceze), vol 2, Tiranë : Akad. e Shkencave e RPS të Shqiperise (Inst. i Historise), 1986; and Teuta (Hoxha), Nuro (Kujtim), Nika (Arta), Bubsi (Almira), op. cit. (For two such collections published in Kosovo, see : Rexha (Illijaz), Lidhja e prizrenit ne dokumente osmane [1878-1881], Prishtine : Arkivi i Kosoves, 1978 ; and Rizaj (Skender), ed., Lidhja Shqiptare e prizrenit ne Dokumentete angleze (1878-1881), Prishtine : Arkivi i Kosoves, 1978 ; for the most recent one published in Albania see : Gaçe (Bardosh), Lëvizja Kombetar në Vlorë (1878-1912), Tiranë : Botimet Toena, 1999.)

103 Reso (Esat), Pikepamjet filozofike, politike dhe shoqerore të Sami Frashërit, Tiranë : 8 Nentori, 1980.

104 Reso (Esad), Sami Frashëri, Pikëpamjet Filozofike, Shqoqërore dhe Politike, Tiranë : Naim Frashëri, 1962. 105 Ibid., p. 9. 
the content of the pedagogical books of Sami are discussed. This part contributes to the myth of Sami in socialist Albania as a "progressive intellectual". In the second part, this myth is repeated by discussing his ideas on "social development" and "the problem of women"106. A new dimension of his mythologization is presented in this part of the book : Sami as an "Albanian nationalist intellectual". For this purpose, Sami's book, Albania - What it was, what it is and what it will become is summarized at great length.

Z. Xholi's book published in 1978 repeats this attitude by declaring that this book of Sami is " the best of Sami's works in Albanian, and the best work of the whole era of National Renaissance, in general "107. However, the author devotes more space to the life-story of Sami, and therefore to his activities for Albanian nationalism. The part on Sami's life-story begins : "Sami Frashëri is a brilliant phenomenon of our culture, one of the figures that represent the works and opinions for Albanian patriotic liberation ${ }^{108}$. This book is different from those of Reso, in the sense of discussing different works of Sami in Turkish and Albanian in a more balanced way, rather than simply summarizing Sami's famous political book. His encyclopaedia and works on language are given two separate short chapters. However, all works of Sami are read with an attitude of selective perception, in the sense that the author ignores Sami's role in the history of Turkish intellectual life and Sami's words that show the sense in which he feels himself a Turk. It is worth noting that Xholi re-wrote these evaluations in a chapter devoted to Sami in his later book on the Thinkers of National Renaissance in $1987^{109}$. There, Xholi informs his readers about the importance of the works of Sami in the intellectual history of Turkey :

the participation in the organisation of the Albanian liberation movement and the publication of the whole works for the Albanian language and schools did not prevent Sami from taking part also in the cultural and political life of the Ottoman Empire. These two activities, one in Albanian and the other in Turkish language, one in the name of Albanian liberation and the other against imperial absolutism, were tightly bound to each other. ${ }^{110}$

However, the author does not try to explain this thesis, but gives information about some of Sami's works, like the Turkish Dictionary, which were important only for Turkish culture.

\footnotetext{
${ }^{106}$ Because of his attitude towards the gender question Sami has been praised also in the Turkish historiography for being "modern", which can be read as "progressive" in the Albanian historiography.

107 Xholl (Zija), Sami Frashëri, Jeta dhe Veprat, Tiranë, 1978, p. 69.

${ }^{108}$ Ibid., p. 7 .
}

109 Xholl (Zlja), Mendimtare të Rilindjes Kombetare, Tiranë : Shtepia Botuese 8 Nentori, 1987, Pp. 287-352.

120 Ibid., p. 327. 
Another monograph, published by Çollaku in 1986, was the most scholarly written one among the others. Again, it is not an historical study, but a discussion of " the thought of the enlightened thinker, Sami Frashëri "111. The author differs from the previous ones in the sense that he refers to almost all of Sami's books both in Albanian and Turkish and to his articles in the press. According to the author, this had not been possible for the other Albanian authors due to the lack of the knowledge of Ottoman language :

the works of the Albanian scholars dedicated to Sami Frashëri bring to the fore the great contribution Sami Frashëri made to the Albanian National question. They also point out his great efforts for rightly orientating our National Movement during the Renaissance period and the part played by him in the development of the Albanian culture, language and school.

In general, the various studies of our several scholars mark a higher stage in the elucidation of the many-sided figure of Sami Frashëri. These studies are distinguished for their scientific objectivity as well as for the sound analyses and the important collusions they draw. But these authors are handicapped by the fact that they are not acquainted with old Turkish which Sami Frashëri's greatest productivity is to be found in.112

In this book, Sami's progressive approach to social and political issues is emphasized more than his Albanian nationalist side, and therefore his political book, discussed at great length by the others, does not occupy much space. In the English abstract at the end of the book, this is justified as follows :

during this period [of the Albanian National Renaissance], our people produced not only fighters for freedom and skilful commanders, but also progressive thinkers who put their deeds at the service of the national liberation and social progress. Sami Frashëri (1850-1904) occupies a place of honour among the Albanian thinkers of the past. ${ }^{113}$

The myth of Sami as an Albanian nationalist is repeated several times in the book, while criticizing the denial of this side in the Turkish historiography. This is stated in the "abstract" as follows :

the works of the Turkish authors dedicated to Sami Frashëri provide important data on the life and activity of the outstanding Albanian Renaissance man. However, all the studies of the Turkish authors are deprived of analyses on the works of Sami Frashëri. Less so do they dwell on the range of problems Sami treats

${ }^{11}$ Çollaku (Shaban), Mendimi iluminist i Sami Frashërit, Tiranë : Akademia e Shkencave e RPS të Shqiperise (Insituti i Historise), 1986.

${ }^{112}$ Ibid., P. 294

113 Ibid., p. 291. 
in his books. The fact they view one-sidedly the work of the Albanian Renaissance man constitutes another deficiency of the monographs of the Turkish authors. They speak very little of the contribution he made to the Albanian National question. Some of them become even tendentious when struggling to put on Sami the attributes of a Turkish scholar. Such is the unsuccessful attempt to deny him the authorship of his masterpiece in Albanian Shqipëria ç'ka qenë, ç'është e ç'do të bëhet. 114

Regarding the scholarly articles in Albanian (directly) on Sami, we can say that different sides of Sami's intellectual activities and works have been studied in depth, and these articles played a very important role in the construction of the myth of Sami in Albania. These articles were usually based on the primary sources and contributed much to the history of Sami's activities. Some of them focus on one dimension of his contribution to the Albanian culture, like (1) education ${ }^{115}$, (2) linguistics ${ }^{116}$, and others on (3) the role of Sami (and his brothers) in the Ottoman history and especially in the history of the Albanian nationalist movement ${ }^{117}$.

Kristo Frashëri's two articles on Sami in 1955 and 1967 can be seen as the best representatives of the general attitude in Albanian scholarly historiography. The first article was the first academic account of Sami's activities in the Albanian nationalist movement of the nineteenth century in socialist Albania ${ }^{118}$. However, the myth of Sami as a progressive and nationalist ideologue is best formulated in the later article. The author uses the works of Sami and some documents from the Albanian archives to prove that Sami was an active participant of the Albanian nationalist movement until $1900^{119}$.

Summarizing the general attitude in the Albanian historiography, we can say that almost all the Albanian writers ignore the fact that Sami was an important figure in the "Turkist" circles of his time and called himself "Turk" in many of his writings.

114 Ibid., pp. 295-296.

115 Dedja (Bedri), " Mbi mendimin pedagogjik të rilindjes (Sami Frashëri) ”, Revista Pedagogjike, (3), 1974 . 116 Xholi (Zija), "Sami Frashëri - Mendimtari, Gjuhëtari e Athetari i Shquar Shqiptar (1850-1904) ", Gjuha Jonë, $4(1), 1984$.

117 Shpuza (Gazmend), art. cit.

${ }^{118}$ Frashëri (K.), "Sami Frashëri ", Buletin për Shkencat Shoqërore, (1), 1955.

119 Frashëri (Kristo), " Shemseddin Sami Frashëri - Ideolog i Lëvizjes Kombëtare Shqiptare ", Studime Historike, (2), 1967 . 


\section{CONCLUSION : SOME GENERAL OBSERVATIONS ON THE COMPARISON OF TWO HISTORIOGRAPHIES}

Although two other members of the Frashëri family (Abdyl and Naim) are accepted as two of the founders of Albanian nationalism by both sides, historians on each side have preferred to emphasize Sami's contributions to their own nation-building and ignored (or in Turkish the case even denied) his importance in the heritage of the other country.

As in the case of popular Turkish historiography, the reason for the use (or reproduction) of a myth and the obstacle for any questioning of it is often as simple as "intellectual laziness" and unprofessional work, rather than ideological blindness, i.e. selective perception due to ideological approach. A striking example of this is two separate entries in an encyclopaedia in Turkish which is a translation from French with many additions and amendments : an entry on Sami in this encyclopaedia carrying the title : "Šemsettin Sami" represents the common mythologization and starts with stating that he was "Turkish", though, as mentioned above, it contains information on Sami's activities as an Albanian intellectual that can not be found in other encyclopaedias. However the editors of the Turkish version of this encyclopaedia did not even recognize that they put another entry in another volume of the same encyclopaedia on Sami with the title "Frașeri (Sami Bey)" which is probably just a translation from the French version. In this entry, which consists of a very brief summary of his activities as a national Albanian intellectual, it is stated that Sami is an "Albanian author" and his book Shqipëria - Ç'ka qënë, ç'është e çdo të bëhetë is his most important work ${ }^{120}$.

Though it seems most interesting, there is not much space here to discuss the question of the instrumental relation of the nationalist historiographers of modern Turkey and socialist Albania with such mythologized historical figures like Sami that they produced, i.e. why they are needed and how they are mis/used for nationalistic purposes. We can see, however, that the production or use of the mythologized image of Sami in both countries derives from the quest of nationalists to make such a historical figure as Sami "their own". This aim becomes the main stimulus to write on him, so that in these writings there is hardly any question that is dealt with, but an attempt to provide as many proofs as possible for the justification of an a priori verdict :

on the level of intentionality, the past treated as myth is fundamentally different from the past treated as history. When good historians write history, their primary objective is to construct, on the basis of the evidence available, as accurate 
and truthful an understanding of the past as possible. Mythologizers, in a sense, do the reverse. Certainly, mythologizers start out with an understanding of the past, which in many (though not all) cases they may sincerely believe to be 'correct'. Their purpose, however, is not to enlarge upon or deepen this understanding. Rather, it is to draw on it to serve the political, ideological, rhetorical, and/or emotional needs of the present. ${ }^{121}$

One of the conclusions about the comparison of two historiographies is that Turkish historiography has hardly been aware of the studies in Albanian historiography, let alone used them as sources. Nor have Sami's own works in Albanian been studied by historians in Turkey. By contrast, Albanian historiographers have always evaluated Sami's works (books, articles in the press, etc.) in both Albanian and Turkish, and some historians have discussed the approach adopted in the Turkish historiography.

Agah Sirrl Levend is an exception to Turkish historiography since he does refer to Albanian historiography. He mentions the French version of the article of Kristo Frashëri mentioned above, but only in a chapter of his book discussing the Albanian nationalism of Sami in light of his much disputed political book on Albania ${ }^{122}$.

The main reason for this neglect on the Turkish side must be simply the lack of knowledge of Albanian, which has never attracted attention as a foreign language in Turkey. However Albanian historiography could actually have been followed by Turkish historians through works published in Turkish or other European languages. Apart from the article of Kristo Frashëri used by Levend as mentioned above, there are books by historiographers of socialist Albania that had been translated into French and English ${ }^{123}$. I think the only reason for not doing this could be intellectual laziness, which may derive from the unwillingness of the nationalist historians to see the other side of the coin that would make the current myth of Sami questionable.

Since Ottoman Turkish used to be the language of the "centre", the written culture of the Albanian speaking people of the Ottoman Empire and the obligatory language for scholars of Albanian history drawing on the (primary and secondary) Ottoman/Turkish sources, there have always been Albanian scholars who can draw on the Turkish sources and follow the Turkish historiography.

There are two peculiar characteristics of the Albanian historiography on Sami during the socialist period. One is a formality that can be seen in almost all history books of that time in Albanian : there is usually at least one quota-

${ }^{223}$ Cohen (Paul A.), op. cit., p. 213.

${ }^{122}$ Levend (Agah Surn), Semsedin Sami (op. cit.), pp. 143-151.

${ }^{123}$ For two of these books see Frashëri (Kristo), The History of Albania (op. cit.) ; and Puto (Arben), Pollo (Stefanaq), op. cit., the latter being translated from French. 
tion or citation from Enver Hoxha, praising Sami for his nationalist and progressive attitudes. The second characteristic is that the authors give preference to the ideas of Sami on social and philosophical questions, used as evidence of his progressive mindedness, as much as to his work on the Albanian question.

Sami was at the same time the creator of one of the first Albanian alphabets, known as the Istanbul alphabet, and a leading figure in the Turkish language reform movement ${ }^{124}$. This fact is acknowledged by the scholars of both sides but each side underestimates the role in the history of the other side. More importantly, his role in the creation of the modern Albanian alphabet, like many other of his contributions to Albanian culture, has been totally ignored by the popular reference books in Turkey.

Those Albanian historians acquainted with Sami's texts where he uses "we" meaning the Turks did not treat this as a problem. However, here we observe that there is little conception of the possibility of an intellectual in that period embracing two collective identities that might have overlapped with each other. "National identity" is principally supposed in the historiography to be singular - one for each person - and developed in reaction to "other" (constructed) national identities. In Sami's case, however, while he was a part of the Albanian "we-group", one of his "other" collective identities was Turkishness.

It is true that Sami used the expressions " our fellow-people, our ancestors " for the Turkic people of Central Asia and " our national language, our mother tongue " for Turkish. He also wrote " we are neither Arabs nor Persian; we are original Turks " and often talked in "we"-form while talking about the Turks. It is also true that Sami played an important role in the "emergence of Turkish nationalism"125 and in the history of "Panturkism"126, but this is only one part of the truth. Sami was also an active participant in Albanian nationalism who played an important role in its transition from cultural nationalism to political nationalism by declaring in his important book in 1899 that there was no other solution than having an independent state ${ }^{127}$. His "separatist" at-

124 Trix (Frances), " The Stamboul Alphabet of Shemseddin Sami Bey : Precursor to Turkish Script Reform ", International Journal of Middle East Studies, (31), 1999, p. 256.

125 Kushner (David), Türk Milliyetçiliğinin Doğușu, İstanbul : Fener, 1998.

${ }^{126}$ Landau (Jacob M.), Pantürkizm, İstanbul : Sarmal, 1999.

${ }^{127}$ For such information in different studies see : Swire (J.), Albania the Rise of a Kingdom, New York : Richard R. Smith, 1930, p. 63 ; Norris (H. T.), Islam in the Balkans : Religion and Society between Europe and the Arab World, London : C. Hurst \& Co, 1993, pp. 163, 166, 188 ; Bartl (Peter), Albanien. Vom Mittelalter bis zur Gegenwart, München : Südosteuropa Institut / Verlag Friedrich Pustet Regensburg, pp. 94-114, 284 ; Duijzings (Ger), Religion and the Politics of Idendity in Kosovo, London : Hurst \& Co, 2000, p. 165 (n. 10$), 167$ (n. 13) ; Bartl (Peter), Milli Bağımsılık Hareketleri Esnasında Arnavutluk Müslümanlan (1878-1912), İstanbul : Bedir Yaynevi, 1998 [1968], pp. 230-237 ; Elsie (Robert), History of Albanian Literature, vol I \& II, Boulder : Colombia University Press, 1995, pp. 241-248, 693-696 ; Vickers (Miranda), The Albanians. A Modern History, London / New York : I. B. Taurus, 1995, pp. 44-45; and Skendi (Stavro), The Albanian National Awakeing, 1878-1912, Princeton : Princeton Univeristy Press, 1967, pp. 119-120, 166-169, 318. 
titude is not easy to acknowledge for the majority of Turkish historiographers and, likewise, has been overemphasized by their Albanian colleagues. They, in turn, did not try to understand all dimensions of Sami's ideas because they neglected Sami's engagement with Turkist circles and the Turkist character of some of his writings.

A fuller account of Sami's ideas cannot be given in this article. However, it is very well known that the production and/or import of myths in Sami's works served the building of both the Albanian and Turkish nations and allowed him to be seen as a "nation-builder" on both sides. I am going to discuss this side of Sami in my future work mentioned at the beginning of this essay, but it is important to note that all these myths were actually produced in Europe, imported from there and spread by the intellectuals of the Ottoman Empire, Sami being only one of them. 